\title{
Temperature and moisture content effects on compressive strength parallel to the grain of paricá
}

\author{
Efeito da temperature e do teor de umidade na \\ resistência à compressão paralela às fibras do paricá
}

\section{Manuel Jesús Manríquez Figueroa Poliana Dias de Moraes Fernanda Almeida Maestri}

\begin{abstract}
$\mathbf{T}$ he aim of this study is to evaluate the effect of the temperature and moisture content on the compressive strength parallel to the grain of paricá (Schizolobium amazonicum Huber ex. Ducke) from cultivated forests. The experiments were carried out on 3 timber samples under different conditions: heated (HT), thermal treatment (TT) and water saturated (WS). The HT sample consisted of 105 clear specimens assembled in 15 groups, the TT consisted of 90 clear specimens assembled in 15 groups and the WS consisted of 90 clear specimens assembled in 9 groups. The specimens from HT and WS samples were tested at a temperature range from 20 to $230^{\circ} \mathrm{C}$ and 20 to $100{ }^{\circ} \mathrm{C}$, respectively. The HT specimens were tested at ambient temperature, but after being submitted to thermal treatment. The HT, TT and WS samples present a decrease in the compressive strength, reaching $65 \%, 76 \%$ and $59 \%$ of the compressive strength at room temperature, respectively. The decrease in the compressive strength of the HT and WS samples can be associated to the thermal degradation of wood polymers and the moisture content. For the TT sample, the strength increased for a pre-heating temperature of up to $170{ }^{\circ} \mathrm{C}$ due to the reduction in the moisture content of the specimens.

Keywords: Timber. Temperature. Moisture content. Compressive strength.

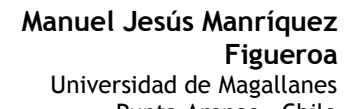

Punta Arenas - Chile

Poliana Dias de Moraes Universidade Federal de Santa Catarina

Florianópolis - SC - Brasil

Fernanda Almeida Maestri Florianópolis - SC - Brasil

Recebido em 23/12/13 Aceito em 18/10/14

\section{Resumo}

O objetivo deste estudo é avaliar o efeito da temperatura e do teorde umidade na resistência à compressão paralela às fibras do paricá (Schizolobium amazonicum Huber ex. Ducke) de florestas plantadas. Os experimentos foram realizados em 3 amostras de madeira em diferentes condições: aquecida (HT), tratamento térmico (TT), e saturada em água (WS). A amostra HT consistiu-se de 105 corpos de prova classificados em 15 grupos, a amostra TT consistiu-se em corpos de prova classificados em 15 grupos, a amostra WS consistiu-se em 90 corpos de prova classificados em 9 grupos. Os corpos de prova das amostras HT e WS foram testados em uma faixa de temperatura de 20 a $230{ }^{\circ} \mathrm{C}$ e de 20 a $100^{\circ} \mathrm{C}$,

respectivamente. Os corpos de prova da amostra HT foram testados à temperatura ambiente, mas após serem submetidos a um tratamento térmico. As amostras HT, TT e WS apresentaram redução da resistência à compressão, as quais atingiram 65\%, 76\% e 59\% da resistência à compressão à temperatura ambiente, respectivamente. A redução da resistência à compressão das amostras de HT e WS pode ser associada à degradação térmica dos polímeros da madeira e da redução do teor de umidade. Para a amostra TT, a resistência dos corpos de prova aumentou para uma temperatura de pré-aquecimento de até $170{ }^{\circ} \mathrm{C}$, devido à redução do teor de umidade.

Palavras-chaves: Madeira. Temperatura. Teor de umidade. Resistência à compressão.
\end{abstract}




\section{Introduction}

The annual production of wood from planted forests in Brazil for 2010 is estimated at 280 million $\mathrm{m}^{3}$ for the production of pulp, energy, laminates, particleboard and plywood (BUAINAIN; BATALHA, 2007). To enhance their use in construction it is necessary to know properly their properties, whether physical or mechanical.

Among several wood species of economic importance in the Amazon region is the paricá (Schyzolobium amazonicum Huber ex. Ducke). According to Colli (2007), the paricá is characterized by fast growth in height and diameter of its usually cylindrical and straight trunk, light color and an average density of 420 kg.m $\mathrm{m}^{-3}$ at $12 \%$ moisture content. Melo, Carvalho and Martins (1989), Terezo and Szücs (2007), Terezo (2010), Scaliante et al. (2011), Vidaurre et al.(2012) and Cavalheiro et al. (2014) studied the mechanical properties of this wood species and showed that it presents good mechanical properties, similar to other species used in building construction. However, in Brazil, there are no studies on the influence of temperature and moisture content on the mechanical strength of the paricá wood species.

The mechanical properties of wood are influenced by several intrinsic and extrinsic factors of this material. The density and moisture content are related to the former. The density has been the subject of many studies (KOLLMANN; CÔTÉ, 1968; BODIG; JAYNE, 1993). In general, when the density increases, mechanical properties such as strength and modules of elasticity, also increase. However, several authors state that the strength and the modulus of elasticity increase to a maximum value as the moisture content of wood decreases to a $0 \%$ moisture content (KOLLMANN; CÔTÉ, 1968; BODIG; JAYNE, 1993; WILSON, 1932; LEONT'EV, 1960; DROW, 1945; GERHARDS, 1982). The temperature is considered an extrinsic factor. When wood is subjected to high temperatures there are changes of colour, thermal degradation and glass transition of its polymers. All these factors cause reduction of the mechanical strength.

Changes in wood colour occur mainly due to the extractive emissions that migrate to the surface during the heating process (BURTIN et al., 1998; MCDONALD, 2000; VIITANIEMI; JAMSA, 2001; SUNDQVIST, 2004). In the thermal degradation of wood, the first carbohydrates to degrade are the hemicelluloses, in the temperature range between 160 and $260{ }^{\circ} \mathrm{C}$, then the cellulose, in the range between 200 and $280{ }^{\circ} \mathrm{C}$ and then the lignin, in the range between 150 and $300{ }^{\circ} \mathrm{C}$ (ROFFAEL; SCHALLER, 1971; FENGEL; WEGENER, 1984; SCHNIEWIND, 1985).

The glass transition of the wood polymers occurs at different temperature levels. For cellulose, the glass transition temperature is in the range of 200 to $250{ }^{\circ} \mathrm{C}$. For hemicelluloses, it is observed in the range of 150 to $220{ }^{\circ} \mathrm{C}$ and for lignin in the range from 180 to $200{ }^{\circ} \mathrm{C}$ (BACK; SALMEN, 1982; IRVINE, 1984). Some national standards for the design of timber structures consider a temperature factor for the calculation of mechanical properties at high temperatures (AMERICAN..., 1997; INSTITUTO..., 2006). However, the European and Brazilian Standards do not consider this temperature factor (NORMALISATION..., 2003; ABNT, 1997).

The aim of this research is to assess the effect of the temperature and the moisture content on the compressive strength parallel to the grain of paricá (Schizolobium amazonicum Huber ex. Ducke) from planted forest in the Amazon region and to present a temperature-dependent factor that should be considered in the design of timber structures.

\section{Materials and methods}

In this section, the materials and methods used to assess the permanent and the temporary effects of the temperature and the moisture content on the compressive strength parallel to the grain of the paricá (Schizolobium amazonicum Huber ex. Ducke) from planted forests are presented.

Tests of the compressive strength parallel to the grain are carried out and the combined effects of temperature and humidity on the mechanical strength are assessed in specimens under three testing conditions: heated (HT), thermally treated and tested at room temperature (TT) and saturated in water (WS) and tested at several levels of temperature. These test conditions were chosen because they can represent the possible situations of moisture content to which the structural elements can be subjected during a fire or firefighting.

\section{Samples and specimens}

In this study, three timber samples were used: one with specimens tested in heated conditions, a sample with specimens thermally treated and tested at room temperature and a sample with watered saturated specimens, tested at different levels of temperatures. These samples are denoted heated sample (HT), thermal treated sample (TT)

18 Figueroa, M, J, M.; Moraes, P. D. de; Maestri, F. A. 
and saturated samples (WS), respectively. The physical properties and characteristics of the samples and the temperature range are shown in Table 1.

The samples were cut of logs $5.6 \mathrm{~m}$ long from juvenile wood. The logs were cut from 19-21 years old trees at a distance of $3.5 \mathrm{~m}$ or higher from the ground. The specimens were prepared with timber classified visually according to the specifications of the Brazilian standard (ABNT, 1997). They were clear, defect-free, straight-grained material cut from regions distant at least $30 \mathrm{~cm}$ of the tip.

The specimen dimensions are those defined in the Brazilian standard, $50 \mathrm{~mm} \times 50 \mathrm{~mm} \times 150 \mathrm{~mm}$ (ABNT, 1997). Cross-section dimensions and length were measured with accuracy of $0.01 \mathrm{~mm}$. Special care was taken in preparing the specimens to ensure that the end surfaces were parallel and that both were aligned perpendicular to the longitudinal axis.

The distribution of specimens in sets was done in order to constitute groups with densities statistically homogeneous. The equivalence was verified by variance analysis. The method used to compare the means was Fisher's least significant difference (LSD) procedure, with a confidence level of $95 \%$ (MONTGOMERY; RUNGER, 2003).

\section{Samples treatment}

The specimens of the HT and TT samples were assembled in 15 groups of 7 and 6 elements, respectively. The specimens of each group were heated at a constant temperature at 20,40, 50, 60, $70,80,90,110,130,150,170,190,210$ and 230 ${ }^{\circ} \mathrm{C}$, during $180 \mathrm{~min}$, in an electric drying oven, in order to ensure homogeneous temperature inside the specimens. The oven had automatic temperature control and internal dimension of 90 $\mathrm{cm} \times 100 \mathrm{~cm} \times 66 \mathrm{~cm}$.

The specimens of the WS sample were assembled in 9 groups of 10 elements, which were water saturated and then heated. The saturation of specimens was performed by submerging them in water at $20{ }^{\circ} \mathrm{C}$ inside a vertical autoclave. The complete saturation was reached after 65 days.

The WS specimens were heated, while immersed in water, during $120 \mathrm{~min}$, at the following temperatures: 20, 30, 40, 50, 60, 70, 80, 90 and $100{ }^{\circ} \mathrm{C}$. They were then removed from the hot water and subjected to mechanical testing in a chamber at the same temperature level.

The specimens of the HT and WS samples were tested in heated conditions while the specimens of TT sample were left to cool for 24 hours in ambient temperature before they were tested.

\section{Mechanical tests}

Compressive strength parallel to the grain tests, at many temperature levels, were carried out in a testing machine with a load cell of $200 \mathrm{kN} \pm 2 \mathrm{kN}$, with an increasing and continuous loading at a constant rate of displacement of $2 \mathrm{~mm} \cdot \mathrm{min}^{-1}$. The tests ended at the rupture of the test specimen, which took 5 to $10 \mathrm{~min}$.

The tests on the specimens from the HT and WS samples were carried out in an environmental chamber with internal dimension of $37 \mathrm{~cm} \times 50 \mathrm{~cm}$ $\times 52 \mathrm{~cm}$ (Figure 1). The specimens from the TT samples were tested under ambient conditions.

\section{Determination of compressive strength parallel to the grain}

Compressive strength values $\left(f_{c o, T}\right)$ for different levels of temperature were calculated according to the Eq. (1) and determined from the ultimate compressive force as illustrated in Figure 2.

$f_{c 0, T}=\frac{F_{c 0, m a ́ x}}{A}$

Eq. 1

Where:

$F_{c 0, \text { máx }}$ is the ultimate force applied to specimens at temperature level $\mathrm{T}$, in $\mathrm{N}$; and

$\mathrm{A}$ is the crosssection of the specimen after the heating, in $\mathrm{mm}^{2}$.

Table 1 - Physical properties and characteristics of the samples

\begin{tabular}{c|c|c|c|c|c|c}
\hline Samples & $\begin{array}{c}\text { Mass density } \\
\text { at 20 }{ }^{\circ} \mathbf{C} \\
\left(\mathbf{k g}^{\mathbf{3}} \mathbf{m}^{\mathbf{3}}\right.\end{array}$ & $\begin{array}{c}\text { Moisture } \\
\text { content at } \\
\mathbf{2 0}{ }^{\circ} \mathbf{C}\end{array}$ & $\begin{array}{c}\text { Temperature } \\
\text { range }\left({ }^{\circ} \mathbf{C}\right)\end{array}$ & Groups & $\begin{array}{c}\text { Specimens } \\
\text { per group }\end{array}$ & $\begin{array}{c}\text { Total } \\
\text { Specimens }\end{array}$ \\
\hline HT & $379 \pm 37$ & 12 & $20-230$ & 15 & 7 & 105 \\
TT & $373 \pm 24$ & 12 & $20-230$ & 15 & 6 & 90 \\
WS & $319 \pm 45$ & 12 & $20-100$ & 9 & 10 & 90 \\
\hline \multicolumn{7}{|r}{} \\
\hline
\end{tabular}


Figure 1 - Specimen and test apparatus

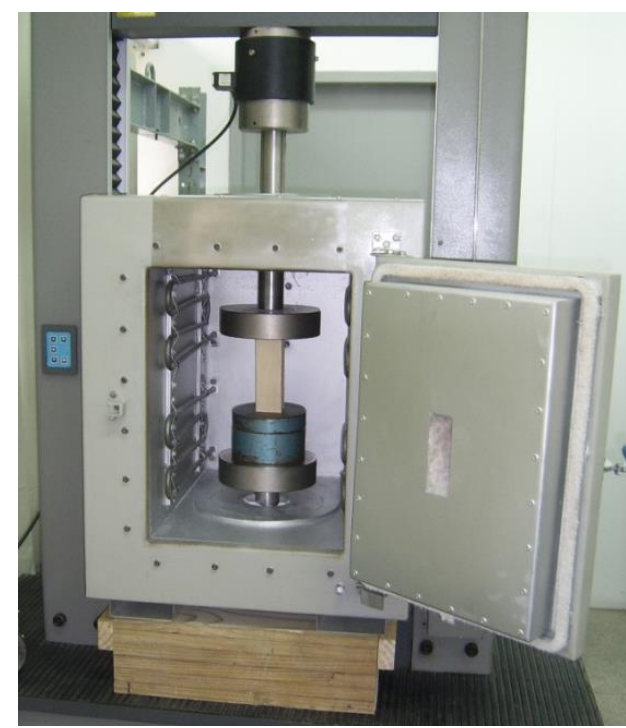

Figure 2 - Force $\times$ displacement curve at a temperature level T

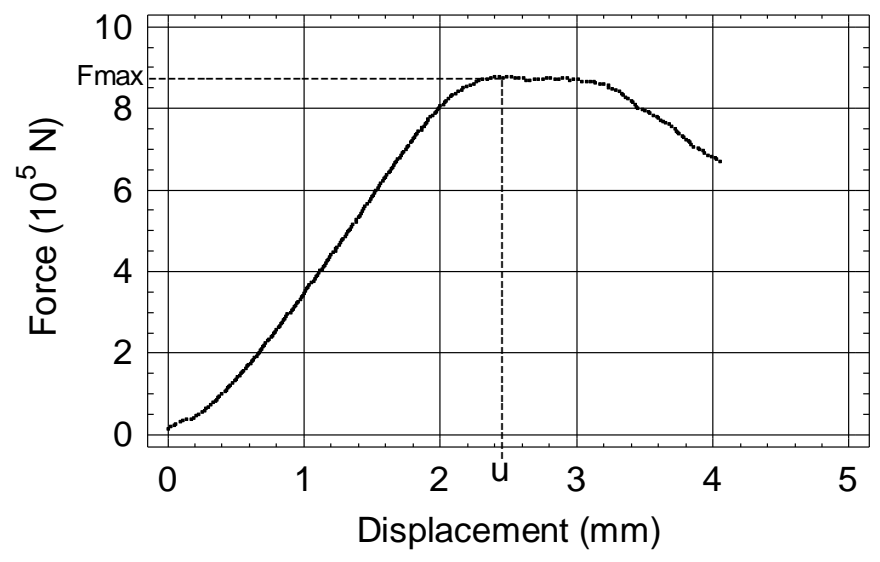

\section{Determination of the moisture content}

The determination of the specimen moisture content during the mechanical test was carried out using the same specimen. After rupture, the specimen was weighted for the determination of the final mass $\left(m_{f}\right)$, and then submitted to drying at a maximum temperature of $103 \pm 2{ }^{\circ} \mathrm{C}$, as required by the Brazilian Standard (ABNT, 1997), until the difference between two consecutive measures was less or equal to $0.5 \%$ of the last measured mass. In this condition, the measured mass is considered to be the dry mass $\left(m_{d}\right.$. The moisture content $(m c)$ was determined by Eq. (2).

$m c=\frac{m_{f}-m_{d}}{m_{d}} \cdot 100$

\section{Results and discussion}

In this section, the results concerning the observed physical changes and the compressive strength parallel to grain of the HT, TT and WS paricá samples are presented. All mechanical data related to the compressive strength were statistically treated.

\section{Moisture content}

Figure 3 shows the moisture content of the specimens from the HT and TT samples. It decreases linearly with the increase of the temperature, presenting $0 \%$ moisture content at $150{ }^{\circ} \mathrm{C}$ for both samples. At temperatures higher than $150{ }^{\circ} \mathrm{C}$, the specimens from the TT sample presented moisture content higher than specimens from the HT sample. This difference is due to moisture absorption by the specimens during the 24 hours cooling period at the laboratory. 
Figure 3 - Moisture content at different levels of temperature

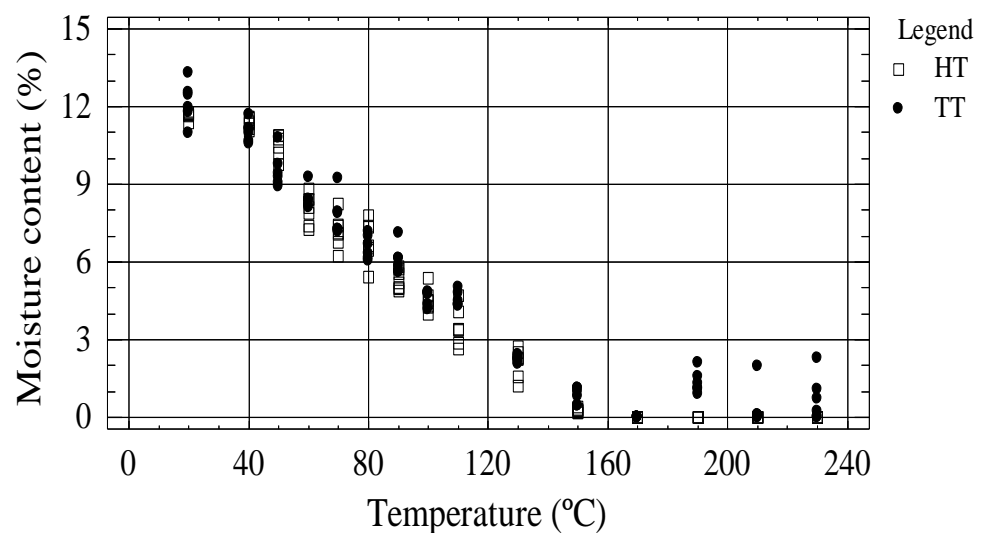

The specimens from the WS sample presented an average moisture content of $191 \%$ during the tests, as expected. According to Colli (2007), the moisture content of saturated samples of Schizolobium amazonicum Huber ex. Ducke, aged 5 and 11 years, varies in the range from 185 to $237 \%$.

According to Schaffer (1973), at $140{ }^{\circ} \mathrm{C}$, the water contained in the components of wood begins to be released and the polymer begins to degrade. As the temperature increases, so does the energy level of the molecules and constituents. This energy is enough to modify the wood internal structure, decreasing the fiber moisture content.

\section{Physical changes of the specimens}

Figures $4 \mathrm{a}, 4 \mathrm{~b}$ and $4 \mathrm{c}$ present the colour changes in the specimens from the 3 samples. These changes were visually verified by comparing with the specimens of groups tested at $20{ }^{\circ} \mathrm{C}$. In the HT and TT samples, changes in wood colour occurred in the internal and external parts of the specimens. These changes were more apparent at higher temperatures, mainly above $150{ }^{\circ} \mathrm{C}$. In these samples, all the specimens heated above $200{ }^{\circ} \mathrm{C}$ presented checking ends caused by fast drying (PONCSÁK et al., 2006). Another physical change observed in these samples was the significant cross section shrinkage, more pronounced at temperatures above $130{ }^{\circ} \mathrm{C}$. This effect was also found by other researchers (BODIG; JAYNE, 1993; KNUDSON; SCHNIEWIND, 1975; ROWELL; YOUNGS, 1981; DINWOODIE, 1989; OLSSON; SALMÉN, 1997; SIMPSON; TENWOLDE, 1999).

The specimens from the WS sample did not present visually significant changes with the temperature increase. According to McCurdy et al. (2006), small colour changes occur under and above the fiber saturation point, caused by the dissolution of extractives present in the wood structure.

As expected, during the specimen saturation, an increase in dimension was found. This is directly related to the theoretical volume of water adhered to the cell wall (KOLLMANN; CÔTÉ, 1968; ROWELL; YOUNGS, 1981).

Many studies found thermally induced changes in the wood colour (BURTIN et al., 1998; MCDONALD et al., 2000; VIITANIEMI; JAMSA, 2001; SUNDQVIST, 2004; MANNINEN; PASANEN; HOLOPAINEN, 2002). They show that the main colour changes begin at $40{ }^{\circ} \mathrm{C}$ and are caused by substances present in wood extractives such as tannins and terpenes, reaction of carbohydrates, aldehydes, phenols and the esterification of resins and waxes for heat treatment.

Although the chemical characteristics of the paricá are not known, the specimen colour changes can be attributed to the same factors found by the mentioned authors.

\section{Specimen failure}

Figures $5 \mathrm{a}, 5 \mathrm{~b}$ and $5 \mathrm{c}$ present the modes of failure that occurred during the compressive tests in the three samples. It was found that the pattern of failure varies according to the test temperature. For the HT sample (Figure 5a), in the range from 20 ${ }^{\circ} \mathrm{C}$ to $110^{\circ} \mathrm{C}$, the shear-type failure occurred along a plane at $55-60^{\circ}$ to the direction of the grain in the middle of the specimens. In the range from 130 to $170{ }^{\circ} \mathrm{C}$, the shear-type failure is near the specimen ends along a plane between 45 and 55 ${ }^{\circ} \mathrm{C}$. At $230{ }^{\circ} \mathrm{C}$, the failure was near the specimen ends along a plane near to $70^{\circ}$ to the direction of the grain. For the TT sample (Figure $5 \mathrm{~b}$ ), in the range from 40 to $70{ }^{\circ} \mathrm{C}$, the shear-type failure plane was at $75^{\circ}$ to the direction of grain, near to the specimen ends. Above $200{ }^{\circ} \mathrm{C}$, the failure was 
by splitting caused by cracking in the specimen top. Bodig and Jayne (1993) state that this pattern occurs by internal failure caused, probably, by charring or inadequate drying due to high temperatures.

The WS sample presented brooming or end rolling-type failure (Figure $5 \mathrm{c}$ ). This failure pattern occurs by wood plasticization when it is under high temperature in a state of complete saturation of the fibres (BODIG; JAYNE, 1993; DINWOODIE, 1981).

\section{Compressive strength parallel to the grain}

Figure 6 presents the compressive strength results for the 3 samples. At room temperature, the HT, TT and WS samples present average strength and standard deviation of $32 \mathrm{MPa} \pm 4 \mathrm{MPa} ; 28 \mathrm{MPa} \pm$ $3 \mathrm{MPa} ; 16 \mathrm{MPa} \pm 3 \mathrm{MPa}$, respectively. Scaliante et al. (2011) found the average of compressive strength of paricá equal to $31 \mathrm{MPa}$, while

\section{Figure 4 - Colour changes}

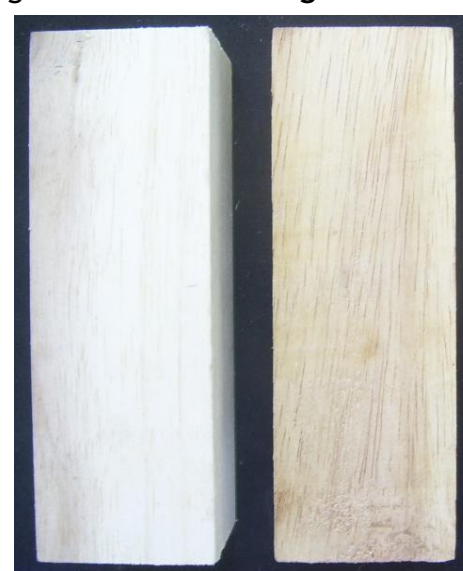

(a) $20^{\circ} \mathrm{C}$ (a) Heated sample (b) $150^{\circ} \mathrm{C}$
Cavalheiroet al. (2014) found the value of $25 \mathrm{MPa}$ These results are similar to the averages of compressive strength of the HT and TT samples.

The results show that, for the HT sample, a continuous strength decrease exists with the increase of temperature up to $80^{\circ} \mathrm{C}$; afterwards, an increase exists up to $150{ }^{\circ} \mathrm{C}$, when the moisture content of the specimens was $0 \%$ (Figure 3). For all specimens from the WS sample, the compressive strength decrease is caused mainly by fiber plasticization as a result of the increase in the temperature level.

The data from the TT sample show that, as the temperature of the thermal treatment increases, the residual strength of the wood also increases to $37 \pm$ $4 \mathrm{MPa}$ at $170{ }^{\circ} \mathrm{C}$. This phenomenon may be due to the reduction of the specimen moisture content, as illustrated in Figure 3. Above $170{ }^{\circ} \mathrm{C}$, the residual strength decrease can be linked to the thermal degradation of the wood components.

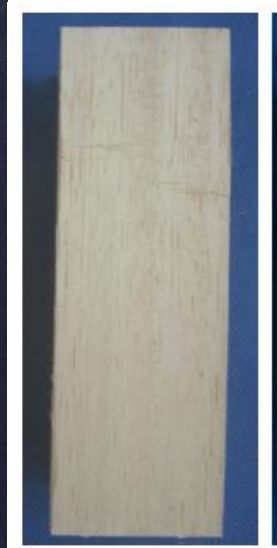

(a) $25^{\circ} \mathrm{C}$

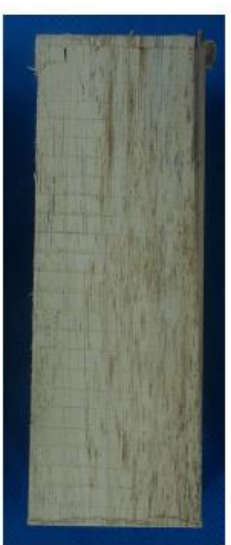

(b) $150^{\circ} \mathrm{C}$

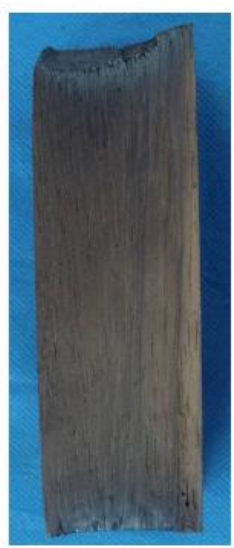

(c) $230^{\circ} \mathrm{C}$ (b) Thermally treated sample

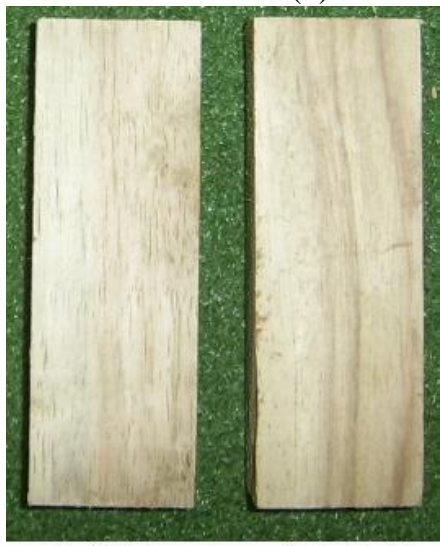

$\begin{array}{ll}\text { (a) } 40{ }^{\circ} \mathrm{C} & \text { (b) } 100^{\circ} \mathrm{C}\end{array}$

(c) Saturated sample 
Figure 5 - Pattern of rupture

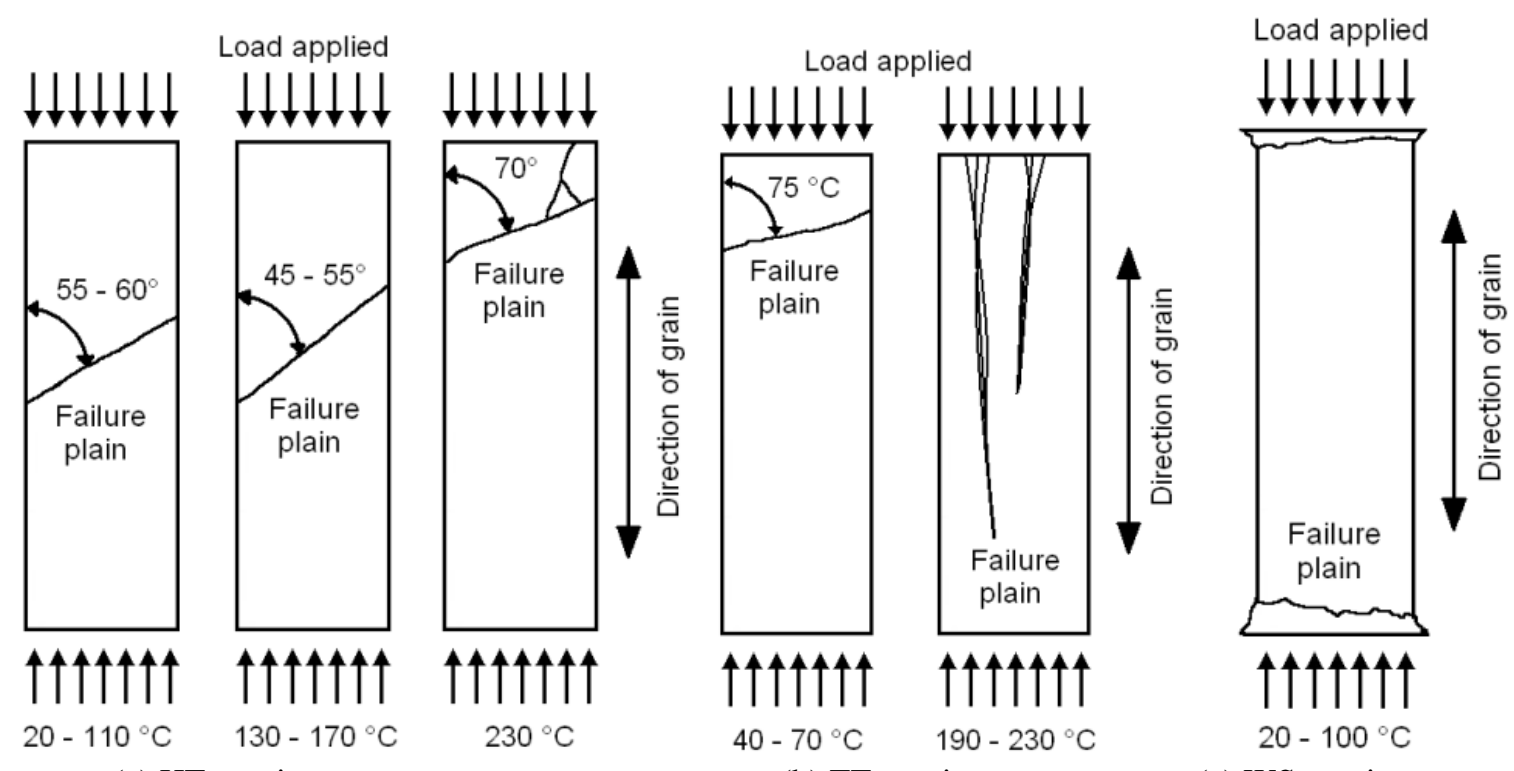

(a) HT specimens

(b) TT specimens

(c) WS specimens

Figure 6 - Compressive strength parallel to the grain at different levels of temperature

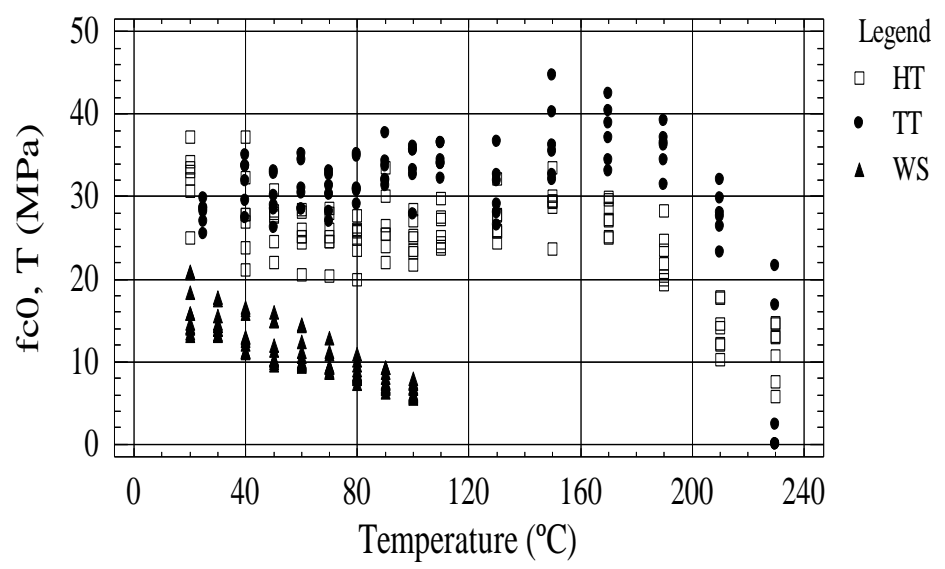

For the HT sample, the analysis of variance indicates that there is a statistically significant difference, with $95 \%$ confidence, between the compressive strength parallel to grain at $20^{\circ} \mathrm{C}$ and the other temperature levels, except at $150{ }^{\circ} \mathrm{C}$. For the TT sample, a difference is found between the data obtained with specimens heated above $90{ }^{\circ} \mathrm{C}$, except those heated at $130{ }^{\circ} \mathrm{C}$ and $210{ }^{\circ} \mathrm{C}$. For the WS sample, there is a difference between the resistance at room temperature and that obtained at other temperature levels, except at $30^{\circ} \mathrm{C}$.

\section{Relative compressive strength}

Table 2 presents, for the three samples, the values of the average compressive strength parallel to the grain divided by the average strength at room temperature, herein called the relative compressive strength. The data show the effect of temperature and humidity on the mechanical strength of wood.

For the HT sample, the strength decreases $23 \%$ at $80{ }^{\circ} \mathrm{C}$. This phenomenon may be associated with the lignin glass transition and the hemicelluloses softening (IRVINE, 1984). Between 90 and 150 ${ }^{\circ} \mathrm{C}$, the strength increases again up to a maximum value, which can be explained by the decrease of the moisture content associated to the increase in cellulose crystallinity in this temperature range (SALMÉN, 1982). Finally, between 170 and 230 ${ }^{\circ} \mathrm{C}$, the strength decreases, probably due to the cellulose thermal degradation (FENGEL, 1967). The strength decrease is not linear and it is $65 \%$ of the strength at room temperature. 
Table 2 - Relative compressive strength and standard deviation

\begin{tabular}{|c|c|c|c|c|c|c|c|}
\hline \multirow{2}{*}{$\begin{array}{c}\mathbf{T} \\
\left({ }^{\circ} \mathbf{C}\right)\end{array}$} & \multicolumn{2}{|c|}{ HT } & \multicolumn{2}{|c|}{ TT } & \multirow{2}{*}{$\begin{array}{c}\mathbf{T} \\
\left({ }^{\circ} \mathbf{C}\right)\end{array}$} & \multicolumn{2}{|c|}{ WS } \\
\hline & $\mathbf{f}_{\mathrm{c} 0} / \mathbf{f}_{\mathrm{c}, 20^{\circ} \mathrm{C}}$ & $\begin{array}{l}\text { Standard } \\
\text { deviation }\end{array}$ & $\mathbf{f}_{\mathrm{c} 0} / \mathbf{f}_{\mathrm{c}, 20^{\circ} \mathrm{C}}$ & $\begin{array}{l}\text { Standard } \\
\text { deviation }\end{array}$ & & $\mathbf{f}_{\mathrm{c} 0} / \mathbf{f}_{\mathrm{c}, 20^{\circ} \mathrm{C}}$ & $\begin{array}{l}\text { Standard } \\
\text { deviation }\end{array}$ \\
\hline 20 & 1.00 & 0.12 & 1.00 & 0.07 & 20 & 1.00 & 0.19 \\
\hline 40 & 0.87 & 0.16 & 1.14 & 0.11 & 30 & 0.92 & 0.12 \\
\hline 50 & 0.84 & 0.09 & 1.07 & 0.11 & 40 & 0.82 & 0.12 \\
\hline 60 & 0.79 & 0.09 & 1.12 & 0.11 & 50 & 0.74 & 0.12 \\
\hline 70 & 0.78 & 0.09 & 1.09 & 0.07 & 60 & 0.69 & 0.12 \\
\hline 80 & 0.77 & 0.06 & 1.14 & 0.11 & 70 & 0.61 & 0.12 \\
\hline 90 & 0.83 & 0.12 & 1.20 & 0.07 & 80 & 0.55 & 0.06 \\
\hline 100 & 0.77 & 0.06 & 1.20 & 0.11 & 90 & 0.48 & 0.06 \\
\hline 110 & 0.80 & 0.06 & 1.24 & 0.07 & 100 & 0.41 & 0.06 \\
\hline 130 & 0.84 & 0.09 & 1.10 & 0.14 & & & \\
\hline 150 & 0.90 & 0.09 & 1.32 & 0.18 & & & \\
\hline 170 & 0.85 & 0.06 & 1.35 & 0.14 & & & \\
\hline 190 & 0.70 & 0.09 & 1.28 & 0.11 & & & \\
\hline 210 & 0.44 & 0.09 & 1.00 & 0.11 & & & \\
\hline 230 & 0.35 & 0.09 & 0.24 & 0.07 & & & \\
\hline
\end{tabular}

The strength values for the TT samples are higher than for the other two samples and the property variation as function of the temperature is not linear (Table 2). At $170{ }^{\circ} \mathrm{C}$, there is a strength increase of $35 \%$ compared to the strength at room temperature. This behavior is caused mainly by the decrease in the specimen moisture content during the test as shown in Figure 3. Then, the strength decreases rapidly, probably due to depolymerization and thermal degradation of wood components (FENGEL; WEGENER, 1984; PONCSÁK et al., 2006). At $230{ }^{\circ} \mathrm{C}$, it is, approximately, $76 \%$ of the strength at room temperature.

In the WS sample, a linear and continuous reduction of the compressive strength was observed as the temperature increased (Table 2). At $100{ }^{\circ} \mathrm{C}$, there is a strength decrease of $59 \%$ compared to that obtained at room temperature. This decrease is due to the temperature tests. Above $170{ }^{\circ} \mathrm{C}$ and $0 \%$ of moisture content, the slope of the average strength for the HT sample is similar to the slope for the WS sample.

\section{Conclusions}

This study evaluated the effect of the temperature and the moisture content on the compressive strength parallel to the grain of paricá (Schizolobium amazonicum Huber ex. Ducke). For the three samples used, the results have shown that:

(a) colour changes occur, both internally and externally to the specimens, with the increase in temperature. These changes are most pronounced at temperatures above $150{ }^{\circ} \mathrm{C}$, probably due to the emissions of volatile organic compound associated with the drying of wood;

(b) at room temperature, the HT, TT and WS samples present average strength and standard deviation of $32 \mathrm{MPa} \pm 4 \mathrm{MPa} ; 28 \mathrm{MPa} \pm 3 \mathrm{MPa}$; $16 \mathrm{MPa} \pm 3 \mathrm{MPa}$, respectively;

(c) there are statistically significant differences, with $95 \%$ confidence, between the results of compressive strength parallel to the grain at $20{ }^{\circ} \mathrm{C}$ and at other temperature levels, except at $150{ }^{\circ} \mathrm{C}$ for the HT sample. For the TT sample, this difference occurs between batches heated above 90 ${ }^{\circ} \mathrm{C}$, except those at $130{ }^{\circ} \mathrm{C}$ and at $210{ }^{\circ} \mathrm{C}$. For the WS sample, the difference is between the strength value at room temperature and those values obtained at other temperature levels, except that at $30{ }^{\circ} \mathrm{C}$;

(d) an increase in temperature causes a decrease in compressive strength parallel to the grain, due to the glass transition of polymers and the thermal degradation of wood. The phenomenon was more pronounced for the WS sample. For the HT sample, at $230{ }^{\circ} \mathrm{C}$, the strength decrease is, approximately, $65 \%$ of the strength at room temperature, while for the TT sample is $76 \%$. For the WS sample, a strength decrease is of $59 \%$ at $100{ }^{\circ} \mathrm{C}$;

(e) for the TT sample, the residual strength increase of $35 \%$ at $170{ }^{\circ} \mathrm{C}$ is mainly due to the decrease in specimen moisture content; $\mathrm{e}$

(f) the decrease in moisture content for the HT and TT samples is linear with the temperature increase. This causes cracks on the tops of the

24 Figueroa, M, J, M.; Moraes, P. D. de; Maestri, F. A. 
specimens above $150{ }^{\circ} \mathrm{C}$, at $0 \%$ of moisture content.

\section{References}

AMERICAN WOOD COUNCIL. ANSI/AF\&PA NDS 1997. National Design Specifican for Wood Construction, American Forest and Paper Association. USA, 1997.

ASSOCIAÇÃO BRASILEIRA DE NORMAS TÉCNICAS. NBR 7190: projeto de estruturas de madeira, anexo G: classificação visual de madeira serrada de coníferas, Projeto CE-02:126.10. Rio de Janeiro, Brasil, 1997.

BACK, E. L; SALMEN, L. Glass Transition of Wood Components Hold Implications ForMolding and Pulping Processes.Tappi Journal, v.65, n.7, p. 107-110, 1982.

BODIG, J.; JAYNE, B. A. Mechanics of Wood and Wood Composities. $2^{\text {nd }}$ ed. Malabar: Publishing Company, 1993.

BUAINAIN, A. M.; BATALHA, M. O. Cadeira Produtiva de Madeira. Brasília: IICA: MAPA/SPA, 2007.

BURTIN, P. et al. Natural Wood Colouring Process in (Juglan ssp), Depends on Native Phenolic Compounds Accumulated in the Transition Zone Between Sapwood and Heartwood. Trees, v. 12, p. 258-264,1998.

CAVALHEIRO, R. S. et al. Propriedades FísicoMecânicas da Madeira de Paricá Utilizando Peças Com Dimensões Estruturais e Corpos de Prova Isentos de Defeitos. In: ENCONTRO BRASILEIRO EM MADEIRAS E EM ESTRUTURAS DE MADEIRA, 14, Natal, 2014. Anais.... João Pessoa: Moura Ramos Gráfica Editora, 2014.

COLLI, A. Caracterização da Madeira de Paricá (Schizolobium amazonicum Huber ex. Ducke) e Propriedades de Chapas de Partículas Aglomeradas Com Diferentes Proporções de Fibras de Coco (Cocos nucifera $\mathrm{L}$ ). Belo Horizonte, 2007. Dissertação (Mestrado em Engenharia Civil) - Escola de Engenharia, Universidade de Viçosa, Belo Horizonte, 2007.

DINWOODIE, J. M. Wood Natures Cellular Polymeric Fibre Composite. London: The Institute of Metals, 1989.

DINWOODIE, J. M.; Timber Its Nature and Behaviour. New York:VanNostrand Reinhold Company Ltd., 1981.
DROW, J. T. Effect of Moisture Constent on the Compressive, Bending, and Shear Strengths, and on the Toughness of Plywood. U.S. For. Serv. Rep. N 1519. U.S. Department Agriculture, Laboratory Forest Produts, Madison, WI, 1945.

FENGEL, D.; WEGENER, G. Wood Chemistry, Ultrastructure, Reactions. Berlin:Walter de Gruyter, 1984.

FENGEL, D. Uber die Veranderungen des Holzes und seiner Komponemtem im Temperaturberiech bis 200C. HolzRoh-Werkstoff, v. 25, p. 102-111, 1967.

GERHARDS, C. C. Effect of the Moisture Content and Temperature on the Mechanical Properties of Wood and Analysis of Immediate Effects. Wood and Fiber, v.14, n.1, p. 4-36,1982.

\section{INSTITUTO NACIONAL DE}

NORMALIZACIÓN. NCh 1198: diseño de cálculo de estructuras en maderas. Santiago, 2006.

IRVINE, G. The Glass Transitions of Lignin and Hemicellulose and Their Measurement by Differential Thermal Analysis.Tappi Journal, v. 67, n. 5, p. 116-121, 1984.

KNUDSON, R. M; SCHNIEWIND, A. P. Performance of Structural Wood Members Exposed to Fire. Forest Product Journal, v.25, n.2, p. 23-32,1975.

KOLlMANN, F. F. P; CÔTÉ, W. A. Jr. Principles of Wood Science and Technology. In: Solid wood. Berlin: Springer, 1968.

LEONT'EV, N. L. The Strength of Wood at Varying Moisture Content. Derev. Prom. v. 10, p. 17-18, 1960.

MANNINEN, A. M.; PASANEN, P.; HOLOPAINEN, J. Comparing the VOC Emissions Between air Dried and Heat-Treated Scots Pine Wood. Atmospheric Environment, v. 36, n. 11, p. 1763-1768, 2002.

MCCURDY, M. C.; PANG, S. R.; KEEY, B. Surface Colour Change in Wood During Drying Above and Below Fiber Saturation Point. Maderas Ciencia y Tecnología, v. 8, n. 1, p. 3140, 2006.

MCDONALD, A. G. et al. The Chemical Nature of Kiln Brown Stain in Radiata Pine.

Holzforschung, v. 54, n. 1, p. 12-22, 2000.

MELO, J. E.; CARVALHO, G. M.; MARTINS, V.A. Espécies Madeireiras Substitutas do Mogno (Swietenia macrophilla King.).Brasília: IBAMA, 1989. (SérieTécnica, 6). 
MONTGOMERY, D. C; RUNGER, G. C. Applied Statistics and Probability For Engineers. $3^{\text {rd }}$ ed. New York: Wiley, 2003.

NORMALISATION FRANÇAISE. EN 1995-1-2 : Eurocode 5 : design of timber structures : part 1-2: general rules-structural fire design. Paris, 2003.

OLSSON, A. M.; SALMÉN, L. Humidity and Temperature Affecting Hemicellulose Softening in Wood. In: INTERNATIONAL CONFERENCE OF COAST ACTION E8, Denmark, 1997. Proceedings...Denmark, 1997.

PONCSÁK, S. et al. Effect of High Temperature Treatment on the Mechanical Properties of Birch (Betulapapyrifera).Wood Science and Technology, v. 40, n. 1, p. 647-663, 2006.

ROFFAEL, E.; SCHALLER, K.The Influence of Thermal Treatment on Cellulose. Holz RohWerkst, v. 20, n. 7, p. 275-278, 1971.

ROWELL, R. M; YOUNGS, R. L. Dimensional Stabilization of Wood in Use. Madison: U. S. Forest Serv.,1981.

SALMÉN, L. The Cell Wall as a Composite Structure: temperature and water induced softening behaviour of wood fiber based materials.PhD Thesis - Department of Paper Technology. The Royal Institute of Technology, Stockholm, Sweden, 1982.

SCALIANTE, R. M. et al. Ensaio de Fluência e de Compressão Paralela às Fibras Para Situações da Madeira à Umidade de Equilíbrio e Saturada.

Madeira: Arquitetura e Engenharia, v. 12, n. 3, p. 19-30, 2011.

SCHNIEWIND, A. P. Concise Encyclopedia of Wood and Wood-Based Materials. New York:Pergamon press, 1985.

SCHAFFER, E.L. Effect of PyrolyticTemperatures on the Longitudinal Strength of Dry Douglas Fir. Journal of testing and evaluation, v.1, n.4, p. 319-329,1973.
SIMPSON, S.; TENWOLDE, A. Mechanical Properties of Wood. In: WOOD HANDBOOK WOOD AS AN ENGINEERING MATERIAL. Madison, 1999.

SUNDQVIST, B. Colour Changes and Acid Formation in Wood During Heating. Doctoral thesis - Luleå University of Technology, Skellefteå Campus, Division of Wood Material Science Sweden, 2004.

TEREZO, R. F.; SZÜCS, C. A. Anatomic and Mechanical Properties of Schizolobium amazonicum at different ages. In: ALL DIVISION 5 CONFERENCE, FOREST PRODUCTS AND ENVIRONMENT, Taipei, Taiwan, 2007. Proceedings...Taipei, Taiwan, 2007.

TEREZO, R. F. Avaliação Tecnológica do Paricá e Seu Uso em Estruturas de Madeira Laminada Colada. Florianópolis, 2010. 200 f. Tese (Doutorado em Engenharia Civil) - Universidade Federal de Santa Catarina, Florianópolis, 2010.

VIDAURRE, G. B. et al.Influência da Idade na Resistência à Flexão e Compressão Paralela da Madeira de Paricá. In: ENCONTRO BRASILEIRO EM MADEIRAS E EM ESTRUTURAS DE MADEIRA,13, Vitória, 2012. Anais....Vitória: UFES, 2012.

VIITANIEMI, P.; JAMSA, S. Heat Treatment of Wood Better Durability WithoutChemicals. In:SPECIAL SEMINAR ON REVIEW ON HEAT TREATMENTS OF WOOD, Antibes, 2001. Proceedings... Antibes, 2001.

WILSON, T. R. C. Strength Moisture Relations For Wood. Washington: USDA tech, 1932.

\section{Acknowledgements}

The authors thank Rodrigo FigueiredoTerezo for providing the wood used in the tests and the Brazilian Research Council (CNPq) for sponsoring this research. 


\section{Manuel Jesús Manríquez Figueroa}

Departamento de Ingenieria en Construccion, Facultad de Ingenieria | Universidad de Magallanes | Avenida Bulnes 01896 | Punta Arenas Chile | Tel.: (56) 6120-7024 | E-mail: manuel.manriquez@umag.cl

\section{Poliana Dias de Moraes}

Departamento de Engenharia Civil, Centro Tecnológico | Universidade Federal de Santa Catarina | Campus Universitário, Trindade |

Florianópolis - SC - Brasil | Caixa-Postal 476 | CEP 88010-970 | Tel.: (48) 3721-9546 | E-mail: poliana.moraes@ufsc.br

\section{Fernanda Almeida Maestri}

Rod. Amaro Antônio Vieira, 2623, ap. 526, Itacorubi | Florianópolis - SC - Brasil | CEP 88034-102 | E-mail: fernandamaestri@gmail.com

Revista Ambiente Construído

Associação Nacional de Tecnologia do Ambiente Construído

Av. Osvaldo Aranha, $99-3^{\circ}$ andar, Centro

Porto Alegre - RS - Brasil

CEP $90035-190$

Telefone: +55 (51) 3308-4084

Fax: +55 (51) 3308-4054

www.seer.ufrgs.br/ambienteconstruido

E-mail: ambienteconstruido@ufrgs.br 